Izvorni članak UDK 130.2(045)

doi: $10.21464 /$ fi 40209

Primljeno 31. 12. 2019.

\author{
Marko Škorić, ${ }^{1}$ Aleksej Kišjuhas ${ }^{2}$ \\ Univerzitet u Novom Sadu, Filozofski fakultet, Dr Zorana Đinđića 2, RS-21000 Novi Sad \\ ${ }^{1}$ mskoric@ff.uns.ac.rs, ${ }^{2}$ aleksej.kisjuhas@ff.uns.ac.rs
}

\title{
Kultura kod ne-ljudskih životinja i evolucijsko podrijetlo ljudske kulture
}

\begin{abstract}
Sažetak
U radu se dovodi u pitanje zamisao o ontološkoj privilegiranosti ljudske vrste, za što smatramo da počiva na brojnim pogrešnim idejama. Jedna je od takvih pogrešnih ideja da je Homo sapiens jedina vrsta koja posjeduje kulturu. Najprije se ističe problematika (definiranja) kulture u kontekstu tzv. minimalističkih i ekspanzionističkih definicija toga fenomena, a zatim se navode primjeri kulturnog ponašanja kod ne-ljudskih životinja. Kritički su analizirane i najčešće komponente za koje se obično smatra da su neophodne da bi se moglo govoriti o istinskoj kulturi, kao što su: društveno učenje, jezik, simboli, teorija uma, povijest, tradicija, prirodna pedagogija i kumulativnost kulture. Naposljetku, istaknute su implikacije jedne adekvatnije, ekspanzionističke i naturalističke, definicije kulture koja je utemeljena na evolucijskim (darvinističkim) osnovama.
\end{abstract}

\section{Ključne riječi}

kultura, ne-ljudske životinje, definiranje kulture, društveno učenje, inovacije, tradicija, evolucija

»Standardnu predodžbu o čovječanstvu kao jedinom obliku života koji je načinio korak od prirodne do kulturne domene - kao da smo jednog dana otvorili vrata k potpuno novom životu - hitno je potrebno ispraviti (...). Ideja da smo jedina vrsta čiji opstanak ovisi o kulturi pogrešna je, a cjelokupno suprotstavljanje prirode i kulture počiva na ogromnom nerazumijevanju.«

(de Waal 2001: 28)

\section{Ontološka (de)privilegiranost Homo sapiensa}

Pod utjecajem antičkih filozofa, a zatim i kršćanskih učenja, ideja o velikom lancu bića (scala naturae) dominirala je filozofijom i znanošću sve do pred kraj devetnaestog stoljeća, kada je Charles Darwin 1859. godine (usp. Darwin 1964) svojom verzijom teorije evolucije ukazao na pogrešnost i neodrživost ideje takvog lanca, temeljem kojega se svijet vidi kao uređenu hijerarhiju na čijem se vrhu nalazi bog, a zatim slijede anđeli, ljudi, životinje, biljke i minerali (usp. Lovejoy 1936). ${ }^{1} \mathrm{U}$ danoj teoriji Bog (ens perfectissimum) i anđeli

Istraživanje je nastalo kao rezultat rada na projektu »Značaj participacije u društvenim mrežama za prilagođavanje evrointegracij- skim procesima« (br. 179037), financiranom od strane Ministarstva prosvete, nauke i tehnološkog razvoja Republike Srbije. 
nemaju materijalna tijela i zato se pretpostavlja da se ne mijenjaju, dok su ljudi jedina bića koja posjeduju i duh i tijelo, odnosno materiju, što ih razlikuje od ostatka živog svijeta koji posjeduje samo tijelo bez duha. To znači da ljudi svoje duhovne atribute dijele s bogom i anđelima, a fizičke sa životinjama.

Preko te ideje o lancu živog svijeta omogućena je konceptualizacija hijerarhijske i nepromjenjive stvarnosti, koja je tijekom povijesti samo modificirana, da bi najpoznatiji oblik dobila s Carlom Linnaeusom u osamnaestom stoljeću (usp. Škorić, Kišjuhas 2012b). S obzirom na to da je tijekom najvećeg dijela povijesti filozofije i znanosti čovjeku pripisivana ontološka privilegiranost $u$ odnosu na druge vrste, ne čudi što je kao jedna od njegovih ekskluzivnih osobina isticana i kultura, odnosno kapacitet za kulturu koji je negiran (ostalim) životinjama. Uz to, čovjeku je čak pripisivana i moć da gotovo u potpunosti transcendira biološki supstrat svoje egzistencije. I danas je jedno od najvažnijih pitanja u znanostima koje proučavaju čovjeka koliki je utjecaj biologije na ljudsko ponašanje i društvene aranžmane, a koliki kulture. Deklarativno, najveći broj znanstvenika zalaže se za interakcionizam, koji prilikom objašnjenja ljudskog ponašanja kombinira biološke i kulturne utjecaje. U praksi je situacija drugačija jer mnoge koncepcije kulture koje potječu iz društvenih znanosti i kulturne antropologije impliciraju zanemarivanje značaja biologije za kulturu.

Osobito su u zapadnoj filozofskoj tradiciji dominirale dihotomije ili opozicije između prirode i kulture, tijela i uma, emocije i razuma, čovjeka i životinja. Danas znamo da su te dihotomije lažne i pogrešne jer nema kulture bez biologije, kao što nema uma bez tijela ili razuma bez emocija, a čovjeka biologija klasificira kao samo jednu od brojnih životinjskih vrsta. Ipak, također nije sporno da je čovjek u stanju da se više od ostalih životinja udalji od svojih bioloških potencijala. Jedno je od najvažnijih pitanja počiva li ljudska priroda (u većoj mjeri) u ljudskosti ili animalnosti, ili je i to lažna dihotomija, o čemu govore i filozofske debate o animalizmu (usp. Olson 1997). Svi pokušaji da se pronađe neko obilježje koje bi posjedovali svi ljudi i nijedan ne-ljudski organizam do sada nisu urodili plodom jer se ispostavilo ili da ga ne posjeduju svi ljudi ili da ga posjeduju i neke druge vrste.

Kultura je dugo vremena smatrana najboljim ili jednim od najboljih kandidata za taj jedinstveni atribut ljudske vrste, tj. kao nešto što ljude kvalitativno razlikuje od ostalih vrsta, uz jezik, racionalnost, religioznost, moralnost itd. Ipak, smatramo da ta »rubikonizacija«, odnosno potraga za demarkacijskom linijom koja kvalitativno razdvaja ljude od ostatka živog svijeta, nije održiva i plodotvorna strategija. Živi svijet karakterizira kontinuitet, odnosno gradualizam, pa se može govoriti o tome da su neka obilježja, za koja se dugo vremena smatralo da karakteriziraju samo ljude, moguće hipertrofirana kod naše vrste, a ne da su ekskluzivno ljudska ili bez filogenetskih korijena kod drugih vrsta. Još je Darwin (usp. Darwin 1882) isticao da priroda ne čini skokove i da ne postoji neki unaprijed osmišljeni plan po kojem se sve razvija, što znači da čovjek nije (bio) nužan proizvod evolucije. Iz toga slijedi da antropocentrizam, kao vrsta specizma ili vrsizma, nema znanstveno opravdanje ako ide dalje od tvrdnje da su ljudi specijalni ili specifični koliko su to i sve ostale vrste, s tim što je onda ta konstatacija trivijalna (usp. Taylor 1984; Benvenuti 2018; Chapman, Huffman 2018; Jürgens 2018).

Dakle, čovjek jednostavno nije specijalna kreacija koja uspijeva transcendirati svoje biološke osnove, a novija istraživanja sve uvjerljivije pokazuju da najčešće spominjana (i navodno) ekskluzivna obilježja ljudske vrste također imaju korijene u evolucijskoj prošlosti. To znači da ljudska kultura potječe 
od ranijih, rudimentarnijih oblika kulture koji se nalaze kod nekih ne-ljudskih životinja. Prije demonstracije tih tvrdnji, pažnju treba posvetiti problemu definiranja kulture, bez ikakvih pretenzija da je moguce ponuditi definiciju koja bi bila svima prihvatljiva. U ovom radu favoriziramo ekspanzionističke definicije kulture jer smatramo da imaju veći potencijal za integraciju prirodnih i društvenih znanosti, kao i da su pogodnije za operacionalizaciju.

\section{Problem (definiranja) kulture: minimalističke i ekspanzionističke definicije}

Jedna od najočiglednijih osobitosti čovjeka jest izuzetna raznolikost načina života ljudske vrste, koju antropologija objašnjava preko koncepta kulture, nesumnjivo jednim od najsloženijih koncepata u društvenim znanostima, o čemu svjedoči njegova povijest, kao i brojne međusobno mahom neuskladive definicije (usp. Harris 2001; Hatch 1973; Vogt 2005). Sredinom dvadesetog stoljeća Alfred Louis Kroeber i Clyde Kluckhohn izdvojili su čak 164 definicije kulture koje su do tada upotrebljavane u znanstvenom diskursu, razlikujući deskriptivne, povijesne, normativne, psihološke, strukturne, genetičke i nepotpune (usp. Kroeber, Kluckhohn 1952). Danas se mogu izdvojiti sljedeće dominantne ideje o kulturi u društvenim znanostima: (1) da se društva ne mogu objasniti jedino prirodnim okruženjem ili čovjekovom biologijom, (2) da postoji bezbroj kulturnih mogućnosti, (3) da su kulture raznovrsne, (4) da su različiti elementi kulture međupovezani i da se pojavljuju putem svojevrsnih obrazaca i (5) da se elementi kulture moraju razumjeti smještanjem u kontekst umjesto njihovog proučavanja u izolaciji (usp. Spillman 2007).

Moderni koncept kulture datira iz 1871. godine, kada ga je formulirao Edward Burnett Tylor:

»Kultura ili civilizacija, shvaćena u svom širokom etnografskom smislu, kompleksna je cjelina koja uključuje znanje, vjerovanje, umjetnost, moral, običaj i bilo koje druge sposobnosti i navike koje je čovjek stekao kao pripadnik društva.« (usp. Tylor 1920: 1)

Na prvi pogled, očigledno je da je u pitanju definiranje kulture preko ljudskog ponašanja, što i danas veliki broj (prvenstveno) društvenih znanstvenika smatra točnim. Međutim, nisu svi klasični mislioci dijelili mišljenje Tylora i po stajalištu njemu sličnih autora. Na primjer, pišući o tzv. superorganskom (što je bio sinonim za kulturu), još je Herbert Spencer (usp. Spencer 1876) taj koncept proširio i na ne-ljudske životinje, posebno spominjući visoko socijalne ptice i sisavce. On je superorgansko shvaćao kao derivat društvenih procesa - ono je stvarni (a ne idealistički) fenomen i podložno je evolucijskim promjenama. Nekoliko desetljeća kasnije, Kroeber, nažalost, fundamentalno mijenja Spencerov pojam (usp. Kroeber 1917) i identificira ga s društvenim procesima, ali dodaje idealističku komponentu, tako da superorgansko postaje novi emergentni proces koji je odvojen od organskog svijeta i karakterizira samo ljudsko ponašanje (usp. Kroeber 1928).

Drukčije rečeno, superorgansko postaje superpsihička, autonomna razina fenomenalne stvarnosti koja je neovisna o procesu biologije i psihologije (usp. Škorić 2016a; Škorić 2016b). Cilj tog projekta bio je da se kulturna antropologija uspostavi kao autonomna znanost, čime bi se spriječila redukcija kulturnih fenomena na »niže« razine stvarnosti poput psihologije i biologije. Većina antropologa i društvenih znanstvenika pratila je liniju koja ide od Tylora i Kroebera, naglašavajući da je kultura jedinstvena ljudskoj vrsti (usp. White 1949), iako nije sporno da su kulturu imali vjerojatno svi hominini pa 
je preciznije reći da se obično misli na to da je Homo sapiens jedina ekstantna vrsta koja ima kulturu.

S vremenom je koncept kulture u društvenim znanostima (p)ostao prilično nejasan. Intuitivno navodno znamo što kultura jest i osjećamo da je važna, ali pokazalo se da je za društvene znanstvenike gotovo nemoguće doći do definicije koja bi bila zadovoljavajuća i koja bi bila adekvatna za operacionalizaciju. Istovremeno, pojedini biolozi s vremenom su sve više pažnje posvećivali upravo problemu kulture (ili »kulture«) kod ostalih (ne-ljudskih) životinja (usp. Bonner 1980; Mundinger 1980; Heyes, Galef 1996; Box, Gibson 1999; de Waal 1982; de Waal 2001; McGrew 2004; Laland, Janik 2006; Laland, Galef 2009; Whiten i dr. 2012; Hoppit, Laland 2013; Ramsay 2013). Dakle, sve veći broj istraživača, osobito iz prirodnih znanosti, koristi pojam kulture da bi se objasnili i raznolikost i transgeneracijski kontinuitet karakterističnih ponašanja kod ne-ljudskih životinja. S tim u vezi, pokušat ćemo pokazati da kod brojnih vrsta postoji međugeneracijska transmisija znanja i vještina koja se odvija ne-genetičkim putem, odnosno da postoji društvena transmisija koja je posljedica interakcija među jedinkama.

Ako se kultura definira odviše usko (što je tipično za društvene znanstvenike), onda se podrazumijeva da će samo čovjek moći zadovoljiti sve kriterije kulturnosti. S druge strane, ako se definira odviše široko, ona lako može izgubiti smisao jer se može ispostaviti da kulturu posjeduju skoro sve vrste (usp. Keesing 1974; Keesing 1990). U svakom slučaju, ako ne sama definicija, onda makar objašnjenje kulture mora sadržavati evolucijsku komponentu jer se ona ne može adekvatno shvatiti bez analize evolucijskih osnova, a tu komponentu možemo prepoznati samo ako je definicija šira (na čemu uglavnom inzistiraju biolozi).

Uvijek će se provlačiti pitanje jesu li usporedbe ljudi i ne-ljudskih životinja samo površinski smislena ili su zaista opravdana (usp. Galef 1992; Laland, Janik 2006; Laland 2008; Laland, Galef 2009) i je li, na primjer, pogrešno govoriti o kulturama i tradicijama ljudskih i ne-ljudskih životinja kao homologijama jer su možda u pitanju samo analogije? U znanstvenom i metodološkom smislu nije jednostavno utvrditi podrijetlo bihevioralnih varijacija unutar vrste - potječu li od društvenog učenja ili od genetskih razlika? S tim u vezi, koliko god se u nekim krugovima isticalo da nema sumnje u to da čimpanze i druge životinje posjeduju kulturu (usp. Bonner 1980; Boesch, Tomasello 1998; McGrew 1998; Boesch 2012b), uvijek je moguće dovesti u pitanje interpretaciju onoga što se može vidjeti u zatočeništvu ili u prirodnom staništu. Zato će prvo biti riječi o dosadašnjim dokazima koji idu u prilog tvrdnji da ne-ljudske životinje posjeduju kulturu, a zatim o najčešće spominjanim komponentama (kulturnom kapacitetu) za koje se obično smatra da su neophodne da bi se moglo govoriti o kulturi.

\section{Primjeri kulturnog ponašanja ne-ljudskih životinja}

Zamisao da ne-ljudske životinje stječu i prenose određene bihevioralne karakteristike putem kulturne imitacije ponašanja drugih životinja ima dugu (pret)povijest, koja se može pratiti još od Aristotela. Isto tako, pojedini rani evolucionisti isticali su naučene ili kulturne tradicije kao izvor adaptivnog ponašanja (usp. Laland, Janik 2006) - na primjer, tzv. Baldwinov efekt (usp. Baldwin 1902) svjedoči o tome da plastičnost prilikom prilagođavanja na okruženje, u što spada i društveno učenje, može stvoriti selekcijske pritiske 
za organske promjene, što potvrđuju i suvremena istraživanja iz domene konstrukcije niša (usp. Odling-Smee, Laland, Feldman 2003; Whiten 2017a).

Nakon objavljivanja Darwinove knjige O podrijetlu vrsta (usp. Darwin 1964) počinje se razvijati moderna komparativna psihologija, ali ubrzo se javljaju kritike usmjerene $\mathrm{k}$ antropocentrizmu u istraživanjima. $\mathrm{U}$ tom kontekstu biva formuliran Morganov kanon (ili princip konzervativizma), kao verzija Occamove britve, a koji se odnosi na interpretaciju životinjskih aktivnosti - prilikom objašnjenja aktivnosti životinja možemo se pozivati na više psihološke procese samo ako se te aktivnosti ne mogu objasniti procesima koji se nalaze niže na ljestvici psihološke evolucije i razvoja (usp. Morgan 1903). Kasnija istraživanja Wolfganga Köhlera i Roberta Yerkesa nedvosmisleno su pokazala da su primati sposobni za više razine spoznaje i manipulaciju alatima (usp. Köhler 1925; Yerkes 1925), a sredinom dvadesetog stoljeća nekoliko neovisnih struja istraživanja uspjelo je pokazati kako kod ne-ljudskih životinjskih vrsta postoje (rudimentarni) oblici kulturne transmisije (usp. Fisher, Hinde 1949; Kawai 1965; Marler, Tamura 1964; Hall, Schaller 1964). U široj javnosti do prvog značajnijeg izazova po zamisao o kulturi kao ekskluzivno ljudskom fenomenu dolazi tijekom 1960-ih godina, kada je Jane Goodall pisala o danas poznatoj činjenici da i čimpanze u prirodnom staništu prave i koriste alate (usp. Goodall, van Lawick 1963; Goodall 1964; za novija istraživanja vidi: Shumaker, Walkup, Beck 2011).

Nakon toga, otkriveno je i da kod brojnih ne-ljudskih životinja postoje kapaciteti za društveno učenje i tradiciju (usp. Box, Gibson 1999; Avital, Jablonka 2000; Hoppitt, Laland 2013; Watson 2018). Iako neke kulturne tradicije neljudskih životinja zaista predstavljaju tek lokalne i specijalizirane ekološke adaptacije, neke životinje nesumnjivo prikazuju raznovrsni kulturni repertoar (usp. Laland, Janik 2006). Na primjer, ornitolozi su otkrili da postoje »kulturno« stečene ili naučene vokalne tradicije kod pjesama ptica pjevica (usp. Catchpole, Slater 1995), a arheološki dokazi pokazuju da neke grupe čimpanzi najmanje 4300 godina održavaju tradiciju otvaranja plodova na određeni način (usp. Mercader i dr. 2007). Te činjenice u vezi s materijalnom kulturom ne-ljudskih životinja percipirane su od strane nekih znanstvenika kao konačni udarac do tada dominantnoj ideji da je kultura differentia specifica ljudske vrste, odnosno da je čovjek jedino biće koje pravi alate i da je samim time jedina vrsta koja posjeduje kulturu.

S vremenom je otkriveno da čimpanze koriste i mnoge druge alate i kulturno specifične inovacije, poput »nakovnja « od drveta ili kamena kako bi razbijali orašaste plodove, sažvakano lišće kojima poput spužve skupljaju teško dostupnu vodu, ali i naoštrene štapove kojima probadaju druge vrste (galagije) (usp. Boesch 1995; Whiten i dr. 1999; Whiten 2014; Gruber i dr. 2015; McGrew 1992; McGrew 2015). Nakon otkrića Goodall, upotreba alata primijećena je $i$ kod slonova (usp. Hart, Hart 1994), vidri (usp. Fujii, Ralls, Tinker 2014), štakora (usp. Nagano, Aoyama 2017), vrana (usp. van Casteren 2017), dabrova (usp. Doucet, Adams, Fryxell 1994), hobotnica (usp. Finn, Tregenza, Norman 2009), riba (usp. Bernardi 2012) i dupina, koji koriste morske spužve kako bi iskopali ribe skrivene na morskom dnu (usp. Krützen i dr. 2005; Mann i dr. 2008). Možda najzanimljiviji slučaj arbitrarne i neadaptivne kulturne tradicije primijećen je kod jedne ženke čimpanze, koja je spontano odlučila nositi travčicu u svom uhu i to u trajanju od najmanje godinu dana, što je bilo ponašanje ili pak »moda « koja je ubrzo imitirana od strane drugih čimpanzi u njenoj grupi (usp. van Leeuwen, Cronin, Haun 2014).

Najveći izazov ili potencijalni problem za eksperimentalno markiranje kulture kod ne-ljudskih životinja zapravo je metodološke prirode. Jedan od bitnih raz- 
loga zbog kojih je bilo potrebno dugo vremena da se uopće otkrije postojanje ne-ljudskih oblika kulture jest nedostatak dugotrajnih terenskih istraživanja i eksperimenata (usp. Whiten i dr. 2017b). S tim u vezi, pojavljuje se i prividni paradoks po kojem, na primjer, postoje bolji ili bar metodološki rigorozniji dokazi za kulturu kod pojedinih vrsta riba nego za kulturu kod primata (usp. Laland, Hoppitt 2003). Svaka »istinska« ne-ljudska kultura podrazumijeva da određene životinje upražnjavaju raznovrsne obrasce ponašanja po grupama u prirodnim populacijama i da su ta ponašanja posljedica društvenog učenja (usp. Heyes, Galef 1996; Hoppitt, Laland 2013). Međutim, osnovni problem u proučavanju, na primjer čimpanzi, jest u tome što s ovom i sličnim vrstama nije jednostavno provoditi eksperimente koji su zadovoljavajući u metodološkom (i etičkom) smislu (usp. McGrew 1998). Za takav je pothvat potrebna eksperimentalna metoda translokacije koja se lako primjenjuje kod pojedinih vrsta riba (usp. Bernardi 2012) i koja bi otklonila sve sumnje da je moguće ekološki faktor, a ne kultura, uzrok različitih ponašanja (usp. Doucet, Adams, Fryxell 1994; Fujii, Ralls, Tinker 2014).

Ipak, još prije dvadesetak godina postojali su uvjerljivi dokazi iz sedam najdužih istraživanja o čimpanzama na osnovi ukupno 151 godine promatranja (usp. Whiten i dr. 1999). Zaključak je da postoje značajne i nesumnjivo kulturne varijacije među populacijama te vrste, kao i da je moguće razlikovati najmanje 39 kulturno različitih obrazaca ponašanja koji nisu prisutni u svim proučavanim grupama (usp. Laland, Janik 2006). U skladu s Morganovim kanonom (usp. Morgan 1903), kod proučavanja primata potrebno je posebno voditi računa o antropocentrizmu istraživača jer nije neuobičajeno da zbog »primatske pristranosti« i želje da se po svaku cijenu pokaže postojanje evolucijskog kontinuiteta među vrstama snize standardi dokazivanja. Usprkos tomu, smatramo da posjedujemo dovoljno dokaza i da opravdano možemo govoriti o opravdanosti postojanja kulturne pantropologije (usp. Whiten, Horner, Marshall-Pescini 2003) ili još općenitije, kulturne biologije (usp. de Waal 2001; Premack 2007).

\section{Društveno učenje, jezik, simboli, teorija uma, povijest, tradicija, prirodna pedagogija i kumulativnost kao (ekskluzivno ljudski) preduvjeti za kulturu}

Autori koji tvrde da ne-ljudske životinje posjeduju kulturu najčešće ističu da je za kulturu neophodno društveno učenje, a kritičari te teze obično napominju da se u obzir moraju uzeti još neke karakteristike: jezik, teoriju uma, povijest, tradiciju, prirodnu pedagogiju, kumulativnu kulturnu evoluciju itd. Svi ti faktori sigurno su od velikog značaja za elaboriranu kulturu koju posjeduje samo čovjek, ali to ne znači da su nužni i za jednostavnije kulturne aranžmane.

Društveno učenje kod ne-ljudskih životinja predstavlja zgodan teren na kojem se može pokazati postojanje mentalnog kontinuiteta u životinjskom svijetu. Radi se o učenju koje je pod utjecajem promatranja drugih jedinki i njihovih proizvoda, odnosno interakcije s drugim jedinkama (obično iste vrste). Ono može uključivati kopiranje obrazaca ponašanja, kopiranje ciljeva ili ishoda (emulacija) ili realnih akcija (imitacija) itd., a rezultat je širenje određenih bihevioralnih obrazaca i bihevioralnog konformizma u populaciji. Taj vid učenja vjerojatno je evoluirao da bi mlade jedinke mogle naučiti razne vještine, $\mathrm{s}$ obzirom na to da je $\mathrm{u}$ tom kontekstu efikasnije od individualnog. $\mathrm{U}$ biti, $\mathrm{u}$ pitanju je kognitivni proces koji se odvija u društvenom kontekstu. Kod vrsta čiji pripadnici brzo sazrijevaju nije potrebno mnogo društvenih instrukcija da 
bi stekli kompetencije odraslih jedinki, ali kod vrsta sa sporim rastom i razvojem te relativno velikim brojem godina provedenih prvenstveno s majkom (npr. čovjekoliki majmuni, kitovi ili slonovi), mladi uče ne samo ponašanje i vještine vrste nego i lokalne kulturne inovacije odnosno kulturu (usp. Whiten 2014).

Dok kritičari napominju da samo postojanje društvenog učenja nije dovoljno da bi se govorilo o kompleksnijim fenomenima poput tradicije i kulture jer ono može proizvesti i samo kratkotrajne učinke, a da se ne proširi u populaciji, ekspanzionisti pak skreću pažnju na to da se ne može sumnjati kako kod mnogih životinjskih vrsta jedinke jedne od drugih uče različite vještine, krikove, pjesme i informacije koje se tiču predatora, partnera ili resursa (usp. Box, Gibson 1999; Laland, Hoppitt 2003; Hoppitt, Laland 2013). U nekim slučajevima, taj prijenos informacija dovoljan je da dovede do difuzije novog ponašanja kroz životinjske populacije i da održi specifične bihevioralne tradicije među različitim populacijama iste vrste (usp. Fragaszy, Perry 2003; Whiten i dr. 2017b). Te tradicije mogu se promatrati kao analogne (ako ne i homologne) ljudskoj kulturi po mnogim karakteristikama, a upotreba tog termina govori samo o tome da je neko ponašanje naučeno društvenim putem. Istovremeno, to nužno ne implicira da su životinje o kojima se radi osobito inteligentne ili da imaju neke posebne lingvističke, kognitivne ili simboličke sposobnosti.

Društveno prenosive informacije mogu se klasificirati u tri grupe, $\mathrm{u}$ ovisnosti o stupnju intencionalnosti u sistemu, koji čine najmanje dvije jedinke, gdje je jedna početnik, a druga model. Najniži je oblik prijenos informacija bez namjere bilo koje strane, zatim postoji oblik u kojem model nema namjere, ali one postoje kod početnika, a najviši oblik postoji kada kod obje individue postoji intencionalnost, što je proces koji se naziva (prirodnom) pedagogijom i predstavlja najefikasniji oblik razmjene društvenih informacija. Autori koji inzistiraju na prirodnoj pedagogiji kao karakteristici koja je tipična samo za ljude (usp. Premack, Premack 1994; Csibra, Gergely 2009; Csibra, Gergely 2011; Gergely, Csibra 2013; za tezu o značaju kulturne pedagogije vidi i: Heyes 2016) tvrde da društveno učenje nije moguće ako se odvija samo putem promatranja. Dakle, bez obzira na to što učenje i podučavanje postoje kod brojnih vrsta, napominje se da one na taj način ne prenose generičko znanje, odnosno znanje koje se može poopćiti. Ipak, sve to ne podrazumijeva nužno da postoji jedan kognitivni faktor koji bi ljude činio jedinstvenim u odnosu na ostale vrste jer su i kognitivni mehanizmi u osnovi prirodne pedagogije nastali od mehanizama koji postoje kod naših predaka. No neki od tih predaka pripadali su drugim vrstama.

Uz pomoć pedagogije, lako se mogu objasniti evolucija kulture i mogućnost povijesti i tradicije, a to su zapravo (kulturne) promjene kroz koje vrsta prolazi, ne mijenjajući se biološki, pa se zaključuje da su čuvanje i promjena kulture prvenstveno pedagoški procesi koji se povezuju s ljudima. Međutim, malo bi tko danas mogao negirati postojanje promjena i razlika među različitim populacijama životinja. Stoga, pitanje oko kojeg postoji spor glasi: jesu li one dovoljno značajne i velike da bi se računale kao kulturna promjena, što znači da se sve opet svodi na (prihvatljivu) definiciju kulture. Kao što se može reći da kod ne-ljudskih životinja (u najmanju ruku) postoji neka vrsta (proto)kulture, tako je evidentno da kod nekih postoji (u najmanju ruku) i (proto)pedagogija. Da bi pedagogija kao međugeneracijska transmisija bila moguća, pedagog i početnik moraju imati kapacitet za pripisivanje mentalnog stanja jedan drugom i za razumijevanje ponašanja drugog preko tih stanja. 
Drugim riječima, moraju posjedovati teoriju uma (usp. Premack, Woodruff 1978; Premack 1988).

Život u grupama predstavlja jedno od ključnih obilježja ljudske evolucije iz mnogo razloga, a u kontekstu ovog rada najvažniji je razvoj tzv. društvenog mozga i teorije uma (usp. Jolly 1966; Humphrey 1976; Whiten, Byrne 1988; Dunbar 2009). Socijalne životinje moraju razumjeti um drugih jedinki da bi opstale, zato što znanje o drugim umovima nudi dodatnu prednost u odnosu na znanje koje se odnosi samo na obrasce ponašanja. I zaista, eksperimenti pokazuju da neke ne-ljudske životinje posjeduju teoriju uma, odnosno da su u stanju drugim jedinkama pripisivati želje i vjerovanja kako bi predvidjeli i objasnili ponašanje (iako je David Premack kao autor prvog istraživanja na čimpanzama poslije promijenio mišljenje i interpretaciju rezultata - usp. Premack, Premack 2003). Dakle, ne postoji konsenzus oko toga kada djeca razvijaju teoriju uma (usp. Wellman 1990; Baillargeon, DeVos 1991), koje je sve vrste imaju (usp. Ruiz 2010; Bugnyar i dr. 2007; Flombaum, Santos 2005; Hare i dr. 1998; Herman i dr. 1999) i imaju li je uopće ne-ljudske životinje (usp. Penn, Povinelli 2007). Ali vjerojatno nema karakteristike koja se smatra važnom za kulturu, a da o njoj postoje nekontroverzni stavovi koji bi bili općeprihvaćeni, o čemu svjedoči i pitanje simbola i jezika.

Najjednostavnije rečeno, simbol je nešto verbalno ili neverbalno u okviru određenog jezika ili kulture što stoji umjesto nečeg drugog i nema očigledne, prirodne ili nužne povezanosti između simbola i onoga što on simbolizira. Klasična kulturna antropologija s kulturom najčešće povezuje upravo simbole, odnosno kapacitet za njihovo stvaranje i razumijevanje, uz to napominjući da taj kapacitet posjeduje samo čovjek (usp. White 1940). Kao i za sve preduvjete kulturnosti, nije ni najmanje sporno da su oni kod čovjeka najkompleksniji u odnosu na ostatak životinjskog svijeta, ali ovdje se radi o demonstraciji teze da čovjekov kapacitet za kulturu ne predstavlja »kvantni skok « u evoluciji.

Ljudska kultura prenosi se prvenstveno jezikom i simboličkim učenjem. Stoga, ona predstavlja povijesnu akumulaciju simboličkog znanja nekog društva. Stupanj kompleksnosti kulture koji postoji kod ljudi vjerojatno nije moguć bez jezika i simboličkog učenja, a podrazumijeva se da simboli nisu međusobno izolirani, već da su povezani u sistemu lingvističkih simbola koji daju značenja objektima, akcijama i apstraktnoj misli. Zato je kontroverzno pitanje imaju li ne-ljudske životinje, osobito primati, sposobnost simbolizirati i koji su točno preduvjeti za simboličko mišljenje. Antropolozi koji umanjuju značaj biologije u društvenom životu obično inzistiraju na tome da je ovo jedinstveno obilježje ljudi, dok primatolozi napominju da ljudi (i neke prijašnje ljudske vrste) nisu jedine životinje koje mogu komunicirati simbolima, iako bi malo tko bio spreman tvrditi da itko osim ljudi može stvoriti simbol »ni iz čega«. Dakle, nije sporno da komunikacija kod ne-ljudskih životinja u najvećoj mjeri nije simbolička i da je najrazvijenija kod ljudi, ali postoje validni podatci i o tome da čovjekoliki majmuni mogu komunicirati s ljudima, ali i međusobno, uz pomoć znakovnog jezika, objekata i leksigrama (tzv. yerkish), koji sadrže neke elemente arbitrarnosti (usp. Premack, Premack 1983).

Kod ljudi je broj individua od kojih se uči uvjerljivo najveći i nema sumnje da kod naše vrste postoje namjere o učenju i podučavanju, dok je kod ne-ljudskih životinja kontroverzno pitanje postoje li i u kojoj mjeri. S druge strane, ne treba isključiti ni mogućnost da je kod ljudi precijenjena uloga društvenog učenja i podučavanja jer literatura o lovcima-sakupljačima ne govori puno o vještinama učenja, a tamo gdje je ono važno i gdje jezik igra najvažniju ulogu, 
mahom se radi o prenošenju normi i mitova grupe ili plemena (usp. Van Schaik 2007). Da bi se adekvatno proučavali kulturni sistemi, potrebno je proučavati i kulturne inovacije, čije je istraživanje veoma rudimentarno kada je riječ o ne-ljudskim životinjama, s mogućim izuzetkom čimpanzi (usp. Boesch 1995; Boesch 2012b; Whiten 2011; Gruber i dr. 2015). Istraživanja su mahom bila usmjerena na procese kulturne transmisije, tako da je zanemarivan aspekt inovativnosti. Kulturne inovacije predstavljaju (nova) rješenja za nove ili stare probleme, pri čemu su obično rezultat neke velike promjene u okruženju. Kao što se individue razlikuju po kapacitetu za inovacije, tako se razlikuju i vrste, što znači da postoje razlike u njihovim repertoarima inovacija.

Navedene inovacije nije uvijek lako proučavati u eksperimentima, laboratorijima ili prirodnim okruženjima, ali nije nemoguće, o čemu svjedoče veoma zanimljiva istraživanja o majmunima kapucinima (usp. Fragaszy i dr. 2017; Perry, Barrett, Godoy 2017). Najveći broj kulturnih varijacija uče mlade životinje, a ne odrasle jedinke, tako da su primjeri poput čovjekolikih majmuna, kod kojih su za društveno učenje zainteresirani i odrasli, zapravo izuzetci. Mladi promatraju starije kao eksperte i od njih uče, a kad se radi o odraslima i njihovom društvenom učenju, kod njih bitnu ulogu igraju i prestižni pripadnici grupe. Dakle, važnu ulogu u tom procesu igraju individualni atributi, ekološki uvjeti i društvena struktura, odnosno društveni status i položaj (usp. Byrne, Russon 1998; Škorić, Kišjuhas 2012a).

Obično se smatra da samo kod ljudi postoji kumulativna kulturna evolucija (usp. Tomasello 1999; Hill, Barton, Hurtado 2009; Mesoudi, Thornton 2018), iako (ni) oko toga ne postoji slaganje. Međutim, čak i autori koji tvrde da se ona može pronaći kod ne-ljudskih životinja govore o tome da je izuzetno rijetka. Taj pojam podrazumijeva postojanje bihevioralnih obrazaca ili obilježja koji su naučeni i prenose se društveno, a koji s vremenom obično postaju sve kompleksniji i efikasniji jer se grade na ranijim kulturnim postignućima, što znači i da ih nijedna individua ne bi sama mogla izmisliti (usp. Boyd, Richerson 1996). Jasno je da su svi postojeći dokazi o kumulativnosti za veliki broj autora kontroverzni jer nisu uvijek jasne razlike među kulturnim gubitkom, promjenom, dodatkom i akumulacijom. Također, kod ljudi se kumulativnost odnosi na više varijabli, u smislu da se kulturni elementi kombiniraju, dok je kod ostalih vrsta vezana mahom za jednu varijablu.

Spomenuto je istraživanje o čuvanju tradicije od 4300 godina kod čimpanzi (usp. Mercader i dr. 2007), ali dok s jedne strane govori o tradiciji, ono isto tako ukazuje i na nedostatak kumulativnosti i na činjenicu da je u pitanju ponašanje koje individua može sama izmisliti (usp. Dean i dr. 2014). Ipak, neka istraživanja demonstriraju kulturnu kumulativnost i kod ne-ljudskih životinja - na primjer, kod japanskih makakija nakon šezdeset godina kulturno naučeno ponašanje pranja gomolja i žitarica postalo je i kompleksnije i efikasnije (usp. Schofield i dr. 2018; Boesch 2003; Boesch 2012b; Hunt, Gray 2003; Yamamoto, Humle, Tanaka 2013; Legare 2017; Sasaki, Biro 2017; Whiten 2019). To će polje istraživanja sigurno još dugo vremena biti kontroverzno, a kao i sa samom kulturom, dosta problematike potječe od nemogućnosti dolaska do općeprihvaćene definicije.

Kada se temeljno razmotre i analiziraju primjedbe koje se upućuju ideji da ne-ljudske životinje posjeduju makar rudimentarnu kulturu, možemo zaključiti sljedeće: najveći broj dilema ima izravne veze s definicijom kulture i to je najveći problem za koji (trenutno) ne postoji rješenje. Jednostavno rečeno, neki autori govore o kvalitativnim razlikama ljudi i ne-ljudskih životinja, a neki o kvantitativnim, ali prave razliku po pitanju »količine« neke osobitosti 
- može li se ona smatrati kulturnom ili ne. Adekvatnije su teorije izgrađene na »kvantitativnosti«, iako je nemoguće pronaći definiciju koja bi zadovoljila obje strane - onu koja po svaku cijenu želi naglasiti kontinuitet i onu koja taj kontinuitet priznaje, ali inzistira na tome da on nije dovoljan da bi se govorilo o kulturi kod ne-ljudskih životinja. U svakom slučaju, istraživanje tog problema može i te kako biti korisno za razumijevanje evolucijskog podrijetla ljudske kulture, a to je lakše postići upravo upotrebom ekspanzionističkih koncepcija kulture.

Nikako ne treba zaboraviti još jednu važnu činjenicu - najčešće su usporedbe ljudske kulture s kulturama čovjekolikih majmuna kao naših najbližih živih srodnika i zato se neke razlike ponekad čine kvalitativnim. Međutim, između čimpanzi i suvremenog čovjeka postojalo je još nekoliko desetina ljudskih vrsta za koje se opravdano može pretpostaviti da su imali sofisticiraniju kulturu od one koju imaju čimpanze pa nije nemoguće zamisliti da bi nam sve te drastične razlike djelovale daleko manje kada bismo imali opsežnije podatke o kulturama svih ljudskih vrsta. Jednostavno rečeno - nije opravdano (iako je to jedino moguće) kulturu Homo sapiensa uspoređivati samo s kulturom čimpanzi i na osnovi toga izvlačiti zaključke o kvalitativnim evolucijskim skokovima jer nemamo relevantne podatke za oko šest milijuna godina tijekom kojih su živjele kulturne vrste, a imale su sofisticiraniju kulturu od čimpanzi i jednostavniju kulturu od današnjih ljudi.

\section{Evolucijske osnove kulture: bestijalizacija ljudi i/ili humanizacija životinja}

Očigledno je da ljudska kultura zaista jest jedinstvena u smislu kompleksnosti i razvijenosti, ali to ne znači da nije izgrađena na nekoj već postojećoj, evoluiranoj ili naturalističkoj osnovi, poput kapaciteta za društveno učenje. Kultura je vjerojatno najuspješnija ljudska adaptacija i sigurno nije nešto superorgansko (usp. Kroeber 1917), već je dio naše biologije, zato što biologija našeg uma i omogućava posjedovanje kulture. Zbog toga su uobičajena suprotstavljanja biologije i kulture (kao i urođenog i stečenog) ne samo umjetna nego i predstavljaju pogrešno shvaćanje kauzalne strukture (živog) svijeta (usp. Plotkin 2007). Ljudsko ponašanje rezultat je procesa genetske i kulturne evolucije koje su djelovale na ljudske populacije u prošlosti (usp. Boyd, Silk 2009; Tooby, Cosmides 1990), a kapacitet za kulturu također je proizvod ili ishod evolucije putem prirodne selekcije. Usprkos tomu što nesumnjivo postoje velike kulturne varijacije među ljudima (i među ljudskim i ne-ljudskim životinjama), one nisu neograničene, a postoje i brojne prekokulturne konstante ili univerzalije čije se podrijetlo ne može objasniti samo difuzijom i interakcijama nego se mora i biologijom, odnosno razmatranjem zajedničkog evolucijskog nasljeđa (usp. Brown 1991; Mameli 2007; Kappeler, Silk 2010).

Zato je zaključak da dihotomija na ljudske i ne-ljudske kulture nije opravdana jer ne postoje samo dvije vrste kulture - ljudska i ne-ljudske (usp. Bonner 1980; Bennett 1992; McGrew 1998; McGrew 2004; Laland, Hoppitt 2003; Whiten i dr. 1999; Laland 2008; Ramsey 2013; Damasio 2018), već mnoge vrste kultura, s obzirom na to da je svaka životinjska vrsta u neurofiziološkom i kulturnom smislu jedinstvena, kao što je i kultura također rezultat univerzalnih i prirodnih evolucijskih procesa (usp. Boyd, Richerson 1985). Charles J. Lumsden i Edward O. Wilson na sličan su način govorili o eukulturi i protokulturi, što je podjela koja se zasniva na kompleksnosti (usp. Lumsden, 
Wilson 1981), ali nam ne govori mnogo o protokulturama jer tu spadaju i sve ne-ljudske kulture. Slično tomu, dihotomne podjele ne ukazuju jasno na evolucijski kontinuitet kultura.

Čak se i kod autora koji nude ekspanzionističke definicije kulture mogu naći brojne definicije, tako da ćemo samo pokušati ilustrirati što bi neka korisna, široka i naturalistička definicija kulture trebala inkorporirati. Može se reći da nije sporno da se kultura gradi na društveno naučenim i društveno prenošenim informacijama, inovacijama i tradicijama (usp. Heyes, Galef 1996; Box, Gibson 1999; Fragaszy, Perry 2003; Hoppitt, Laland 2013), odnosno da se ne odnosi na naslijeđene genetske informacije ili na znanje i vještine koje individue same za sebe stječu u određenom ekološkom kontekstu. Informacije koje se prenose društvenim putem predstavljaju osnovu obrazaca ponašanja koji su tipični za neku grupu, a koji su inovativni, kumulativni i mogu varirati među populacijama (usp. Boesch 1995; McGrew 1998; Whiten i dr. 1999; van Leeuwen, Cronin, Haun 2014; Perry, Barrett, Godoy 2017; Schofield i dr. 2018).

Kritičari ideje o tome da ne-ljudske životinje posjeduju kulturu (usp. Premack, Hauser 2006) napominju da nije definicija kulture najvažnija za tu problematiku, već da je to teorija kulture, koja može razlikovati trivijalna ponašanja od onih relevantnih i s ozbiljnim posljedicama. Ipak, tu se opet javljaju neslaganja oko toga kako se prenose značajne kulturne prakse, kao i to koje su prakse značajne. Najjednostavnije informacije koje se prenose među jedinkama zaista jesu one koje se tiču hrane, plijena ili neposrednog okruženja. Stoga je pravo pitanje gdje treba povući granicu kada se radi o trivijalnosti ili velikom značaju za društveni/kulturni život.

Da se ne bi činilo da su ekspanzionističke definicije kulture suviše blage i široke, moguće je ponuditi i nekoliko striktnijih kriterija koji bi morali biti zadovoljeni prije nego što bi se neko ponašanje zaista nazvalo kulturnim (usp. Kroeber 1928; McGrew, Tutin 1978; McGrew 1992): (1) inovacija - izum ili modifikacija novih obrazaca, (2) diseminacija - individue usvajaju obrazac od inovatora, (3) standardizacija - oblik obrasca konzistentan je i stiliziran, (4) trajnost - obrazac se izvodi i bez prisustva demonstratora, (5) difuzija - obrazac se širi iz jedne grupe u drugu, (6) tradicija - obrazac traje i opstaje u sljedećoj generaciji, (7) neovisnost o opstanku - obrazac nadilazi puki opstanak (ne zadovoljava samo potrebu opstanka), (8) prirodnost - obrazac se može uočiti i bez direktnog ljudskog utjecaja. Istraživanja koja su navedena u ovom radu uglavnom govore o nekim od tih kriterija, a ponekad i o svim (usp. Whiten 2019).

Akumulacija primjera o kulturnom ponašanju ne-ljudskih životinja ponudila je mnoštvo dokaza o kulturnim vještinama i kapacitetima, ako ne i o istinskim etnografijama brojnih živih vrsta. Zbog toga se danas vjerojatno više i ne radi o pitanju imaju li životinje kulturu, koliko o pitanju što točno (ne) razlikuje kulturne sposobnosti čovjeka od kulturnih sposobnosti ostalih ili ne-ljudskih životinja (usp. Boesch 2012a). Ukoliko je kultura naprosto način na koji radimo i mislimo o stvarima, a koji se prenosi ne-genetskim putem, utoliko se ljudska kultura od ostalih oblika najviše razlikuje po tome što se dijeli i prenosi, a ne kako se dijeli i prenosi.

S obzirom na to da su ljudi, kao i svi ostali organizmi, vremenom evoluirali, to znači da i ljudski um i njegove psihološke karakteristike također imaju evolucijsko podrijetlo. Zbog toga je evolucijski pristup veoma koristan i plodan kada se radi o razumijevanju kulture, kako ljudi, tako i ne-ljudskih životinja. Ljudi se od ne-ljudskih životinja ne razlikuju toliko u domeni fizičke spozna- 
je, koliko na terenu društvene spoznaje (usp. Shettleworth 2010), a to je polje koje u najvećoj mjeri prikazuje ljudske specifičnosti u odnosu na njihove evolucijske pretke i najbliže srodnike. Zato se možda može zaključiti da problem kulture ipak pokazuje kontinuitet u procesu, ali i da moguće postoji određeni diskontinuitet po pitanju učinaka kulturnosti (usp. Read 2012).

\section{Literatura}

Avital, Eytan; Jablonka, Eva, Animal Traditions: Behavioural Inheritance in Evolution, Cambridge University Press, Cambridge 2000.

Baillargeon, Renée; DeVos, Julie,»ObjectPermanence in Young Infants: Further Evidence«, Child Development 62 (1991) 6, str. 1227-1246, doi: https://doi.org/10.2307/1130803.

Baldwin, James Mark, Development and Evolution, Macmillan, New York 1902.

Benvenuti, Anne, »Good news: Humans are neither distinct nor superior«, Animal Sentience 23 (2018) 3, str. 1-4.

Bernardi, Giacomo, »The use of tools by wrasses (Labridae)«, Coral Reefs 31 (2012) 1, str. 39-39.

Boesch, Christophe, »Innovation in wild chimpanzees (Pan troglodytes)«, International Journal of Primatology 16 (1995) 1, str. 1-16, doi: https://doi.org/10.1007/BF02700150.

Boesch, Christophe; Tomasello, Michael, »Chimpanzee and human cultures«, Current Anthropology 39 (1998) 5, str. 591-614, doi: https://doi.org/10.1086/204785.

Boesch, Christophe, »Is culture a golden barrier between human and chimpanzee? «, Evolutionary Anthropology 12 (2003) 2, str. 82-91, doi: https://doi.org/10.1002/evan.10106.

Boesch, Christophe, »From Material to Symbolic Cultures: Culture in Primates «, u: Valsiner, Jaan (ur.), The Oxford Handbook of Culture and Psychology, Oxford University Press, New York 2012., str. 677-692, doi: https://doi.org/10.1093/oxfordhb/9780195396430.013.0032. [2012a]

Boesch, Christophe, Wild Cultures: Comparison between Chimpanzee and Human Cultures, Cambridge University Press, Cambridge 2012., doi: https://doi.org/10.1017/ CBO9781139178532. [2012b]

Bonner, John Tyler, The Evolution of Culture in Animals, Princeton University Press, Princeton 1980 .

Box, Hilary O.; Gibson, Kathleen Rita (ur.), Mammalian Social Learning: Comparative and Ecological Perspectives, Cambridge University Press, Cambridge 1999.

Boyd, Robert; Richerson, Peter J., Culture and the Evolutionary Process, University of Chicago Press, Chicago 1985.

Boyd, Robert; Richerson, Peter J., »Why culture is common, but cultural evolution is rare«, u: Runciman, Walter Garrison; Smith, John Maynard; Dunbar, Robin Ian MacDonald (ur.), Evolution of Social Behaviour Patterns in Primates and Man: A Joint Discussion Meeting of the Royal Society and the British Academy, sv. 88, Oxford University Press, Oxford 1996., str. 77-93.

Boyd, Robert; Silk, Joan B., How Humans Evolved, W. W. Norton \& Company, New York, London 2009.

Brown, Donald E., Human Universals, McGraw Hill, Boston 1991.

Bugnyar, Thomas et al., »Ravens Judge Competitors through Experience with Play Caching «, Current Biology 17 (2007) 20, str. 1804-1808.

Byrne, Richard William; Whiten, Andrew (ur.), Machiavellian Intelligence: Social Expertise and the Evolution of Intellect in Monkeys, Apes, and Humans, Clarendon Press, Oxford 1988.

Byrne, Richard William; Russon, Anne E., »Learning by imitation: A hierarchical approach«, Behavioral and Brain Sciences 21 (1998) 5, str. 667-684, doi: https://doi. org/10.1017/S0140525X98001745. 
Catchpole, Clive K.; Slater, Peter J. B., Birdsong: Biological Themes and Variations, Cambridge University Press, Cambridge 1995.

Chapman, Colin A.; Huffman, Michael A., »Why do we want to think humans are different? «, Animal Sentience 23 (2018) 1, str. 1-8.

Csibra, Gergely; Gergely, György, »Natural pedagogy«, Trends in Cognitive Science 13 (2009) 4, str. 148-153, doi: https://doi.org/10.1098/rstb.2010.0319.

Csibra, Gergely; Gergely, György, »Natural pedagogy as evolutionary adaptation «, Philosophical Transactions of the Royal Society B Biological Sciences 366 (2011) 1567, str. 1149-1157, doi: https://doi.org/10.1098/rstb.2010.0319.

Damasio, Antonio, The Strange Order of Things: Life, Feeling, and the Making of Cultures, Pantheon Books, New York 2018.

Darwin, Charles, The Descent of Man, and Selection in Relation to Sex, John Murray, London 1882.

Darwin, Charles, On the Origin of Species by Means of Natural Selection, or the Preservation of Favoured Races in the Struggle for Life, Harvard University Press, Cambridge, London 1964.

Dean, Lewis G. et al., »Human cumulative culture: A comparative perspective«, Biological Reviews 89 (2014) 2, str. 284-301, doi: https://doi.org/10.1111/brv.12053.

de Waal, Franciscus Bernardus Maria, Chimpanzee Politics: Power and Sex Among Apes, Jonathan Cape, London 1982.

de Waal, Franciscus Bernardus Maria, The Ape and the Sushi Master: Cultural Reflections by a Primatologist, Penguin, London 2001.

Doucet, Christine M.; Adams, Ian T.; Fryxell, John M., »Beaver dam and cache composition: Are woody species used differently?«, Ecoscience 1 (1994) 3, str. 268-270, doi https://doi.org/10.1080/11956860.1994.11682251.

Dunbar, Robin Ian MacDonald, »The social brain hypothesis and its implications for social evolution «, Annals of Human Biology 36 (2009) 5, str. 562-572, doi: https://doi.org/10.1 080/03014460902960289.

Fisher, James; Hinde, Robert Aubrey, »The opening of milk bottles by birds«, British Birds 42 (1949), str. 347-357.

Finn, Julian K.; Tregenza, Tom; Norman, Mark D., »Defensive tool use in a coconutcarrying octopus«, Current Biology 19 (2009) 23, str. R1069-R1070, doi: https://doi. org/10.1016/j.cub.2009.10.052.

Flombaum, Jonathan I.; Santos, Laurie R., »Rhesus monkeys attribute perceptions to others«, Current Biology 15 (2005) 5, str. 447-452, doi: https://doi.org/10.1016/ j.cub.2004.12.076.

Fragaszy, Dorothy M.; Perry, Susan (ur.), The Biology of Traditions: Models and Evidence, Cambridge University Press, Cambridge 2003.

Fragaszy, Dorothy M. et al., »Synchronized practice helps bearded capuchin monkeys learn to extend attention while learning a tradition «, Proceedings of the National Academy of Sciences 114 (2017) 30, str. 7798-7805, doi: https://doi.org/10.1073/pnas.1621071114.

Fujii, Jessica A.; Ralls, Katherine; Tinker, Martin Tim, »Ecological drivers of variation in tool-use frequency across sea otter populations«, Behavioral Ecology 26 (2014) 2, str. 519-526. doi: https://doi.org/10.1093/beheco/aru220.

Galef, Bennett G., »The question of animal culture«, Human Nature 3 (1992) 2, str. $157-178$

Gergely, György; Csibra, Gergely, »Natural pedagogy«, u: Banaji, Mahzarin R.; Gelman, Susan A. (ur.), Navigating the Social World: What Infants, Children, and Other Species Can Teach Us, Oxford University Press, Oxford 2013., str. 127-132.

Goodall, Jane; van Lawick, Hugo, »My life with the wild chimpanzees«, National Geographic 124 (1963) 2, str. 272-308. 
Goodall, Jane, »Tool-using and aimed throwing in a community of free-living chimpanzees«, Nature 201 (1964) 4926, str. 1264-1266, doi: https://doi.org/10.1038/2011264a0.

Gruber, Thibaud et al., »The spread of a novel behavior in wild chimpanzees: New insights into the ape cultural mind «, Communicative \& Integrative Biology 8 (2015) 2, str. e1017164, doi: https://doi.org/10.1080/19420889.2015.1017164.

Hall, K. R. L.; Schaller, George B., »Tool-using behavior of the California sea otter«, Journal of Mammalogy 45 (1964) 2, str. 287-298.

Hare, Brian; Call, Josep; Tomasello, Michael, »Communication of food location between human and dog (Canis Familiaris)«, Evolution of Communication 2 (1998) 1, str. 137159, doi: https://doi.org/10.1075/eoc.2.1.06har.

Hart, Benjamin L.; Hart, Lynette A., »Fly switching by Asian elephants: Tool use to control parasites «, Animal Behaviour 48 (1994) 1, str. 35-45, doi: https://doi.org/10.1006/ anbe.1994.1209.

Herman, Louise M. et al., »Dolphins (Tursiops truncatus) comprehend the referential character of the human pointing gesture «, Journal of Comparative Psychology 113 (1999) 4, str. 347-364, doi: https://doi.org/10.1037/0735-7036.113.4.347.

Heyes, Cecilia M.; Galef, Bennett G. (ur.), Social Learning in Animals: The Roots of Culture, Academic Press, San Diego 1996.

Heyes, Cecilia, »Born pupils? Natural pedagogy and cultural pedagogy «, Perspectives on Psychological Science 11 (2016) 2, str. 280-295.

Hill, Kim; Barton, Michael; Hurtado, A. Magdalena, »The emergence of human uniqueness «, Evolutionary Anthropology: Issues, News, and Reviews 18 (2009) 5, str. 187-200, doi: https://doi.org/10.1002/evan.20224.

Hoppitt, William; Laland, Kevin N., Social Learning: An Introduction to Mechanisms, Methods and Models, Princeton University Press, Princeton 2013.

Humphrey, Nicholas K., »The social function of intellect«, u: Bateson, Patrick P. G.; Hinde, Robert Aubrey (ur.), Growing Points in Ethology, Cambridge University Press, Cambridge 1976., str. 303-317.

Hunt, Gavin R.; Gray, Russell D., »Diversification and cumulative evolution in New Caledonian crow tool manufacture «, Proceedings of the Royal Society B: Biological Sciences 270 (2003) 1517, str. 867-874, doi: https://doi.org/10.1098/rspb.2002.2302.

Jolly, Alison, »Lemur Social Behavior and Primate Intelligence«, Science 153 (1966) 3735, str. 501-506, doi: https://doi.org/10.1126/science.153.3735.501.

Jürgens, Uta Maria, »Human and honhuman animals: Equals in uniqueness «, Animal Sentience 23 (2018) 2, str. 1-3.

Kappeler, Peter M.; Silk, Joan B. (ur.), Mind the Gap: Tracing the Origins of Human Universals, Springer, Dordrecht 2010.

Kawai, Masao, »Newly acquired pre-cultural behaviour of the natural troop of Japanese monkeys on Koshima Islet«, Primates 6 (1965), str. 1-30, doi: https://doi.org/10.1007/ BF01794457.

Keesing, Roger M., »Theories of culture«, Annual Review of Anthropology 3 (1974), str. 73-97, doi: https://doi.org/10.1146/annurev.an.03.100174.000445.

Keesing, Roger M., »Theories of culture revisited «, Canberra Anthropology 13 (1990) 2, str. 46-60.

Köhler, Wolfgang, The Mentality of Apes, Routledge \& Kegan Paul, London 1925.

Kroeber, Alfred L., »The superorganic«, American Anthropologist 19 (1917) 2, str. 163-213.

Kroeber, Alfred L., »Sub-human cultural beginnings«, Quarterly Review of Biology 3 (1928) 3, str. 325-342.

Kroeber, Afred L.; Kluckhohn, Clyde, Culture: A Critical Review of Concepts and Definitions, Peabody Museum of American Archaeology and Ethnology, Harvard University, Cambridge 1952. 
Krützen, Michael et al., »Cultural transmission of tool use in bottlenose dolphins «, Proceedings of the National Academy of Sciences 102 (2005) 25, str. 8939-8943, doi: https:// doi.org/10.1073/pnas.0500232102.

Laland, Kevin N.; Hoppitt, William, »Do animals have culture? «, Evolutionary Anthropology: Issues, News, and Reviews 12 (2003) 3, str. 150-159, doi: https://doi.org/10.1002/ evan.10111.

Laland, Kevin N.; Janik, Vincent M., » The animal cultures debate «, Trends in Ecology and Evolution 21 (2006) 10, str. 542-547.

Laland, Kevin N., »Animal cultures«, Current Biology 18 (2008) 9, str. PR366-R370, doi: https://doi.org/10.1016/j.cub.2008.02.049.

Laland, Kevin N.; Galef, Bennett G. (ur.), The Question of Animal Culture, Harvard University Press, Cambridge 2009.

Legare, Christine H., »Cumulative cultural learning: Development and diversity «, Proceedings of the National Academy of Sciences 114 (2017) 30, str. 7877-7883, doi: https:// doi.org/10.1073/pnas.1620743114

Lovejoy, Arthur O., The Great Chain of Being: A Study of the History of an Idea, Harvard University Press, Cambridge 1936.

Lumsden, Charles J.; Wilson, Edward Osborne, Genes, Mind and Culture: The Coevolutionary Process, Harvard University Press, Cambridge 1981

Mameli, Matteo, »Evolution and psychology in philosophical perspective«, u: Barrett, Louise; Dunbar, Robin Ian MacDonald (ur.), Oxford Handbook of Evolutionary Psychology, Oxford University Press, Oxford 2007., str. 21-34.

Mann, Janet et al., »Why do dolphins carry sponges?«, Plos One 3 (2008) 12, str. e3868, doi: https://doi.org/10.1371/journal.pone.0003868.

Marler, Peter; Tamura, Miwako, »Culturally transmitted patterns of vocal behavior in sparrows«, Science 146 (1964) 3650, str. 1483-1486.

Marticorena, Drew C. W. et al., »Monkeys represent others' knowledge but not their beliefs «, Developmental Science 14 (2011) 6, str. 1406-1416.

McGrew, William C.; Tutin, C. E. G., »Evidence for a social custom in wild chimpanzees? «, Man 13 (1978) 2, str. 234-251.

McGrew, William C., Chimpanzee Material Culture: Implications for Human Evolution, Cambridge University Press, Cambridge 1992.

McGrew, William C., »Culture in nonhuman primates? «, Annual Review of Anthropology 27 (1998), str. 310-328, doi: https://doi.org/10.1146/annurev.anthro.27.1.301.

McGrew, William C., The Cultured Chimpanzee: Reflections on Cultural Primatology, Cambridge University Press, Cambridge 2004.

McGrew, William C., »The cultured chimpanzee: Nonsense or breakthrough?«, Human Ethology Bulletin 30 (2015) 1, str. 41-52.

Mercader, Julio et al., »4,300-year-old chimpanzee sites and the origins of percussive stone technology«, Proceedings of the National Academy of Sciences 104 (2007) 9, str. 3043-3048.

Mesoudi, Alex; Thornton, Alex, »What is cumulative cultural evolution? «, Proceedings of the Royal Society B: Biologial Sciences 285 (2018) 1880, str. 20180712, doi: https://doi. org/10.1098/rspb.2018.0712.

Morgan, Conwy Lloyd, An Introduction to Comparative Psychology, Walter Scott Publishing, London 1903.

Mundinger, Paul C., »Animal cultures and a general theory of cultural evolution«, Ethology and Sociobiology 1 (1980) 3, str. 183-223.

Nagano, Akane; Aoyama, Kenjiro, »Tool-use by rats (Rattus norvegicus): Tool-choice based on tool features«, Animal Cognition 20 (2017) 2, str. 199-213, doi: https://doi. org/10.1007/s10071-016-1039-5. 
Odling-Smee, F. John; Laland, Kevin N.; Feldman, Marcus W., Niche Construction: The Neglected Process in Evolution, Princeton University Press, Princeton 2003.

Olson, Eric T., The Human Animal: Personal Identity Without Psychology, Oxford University Press, New York 1997.

Penn, Derek C.; Daniel J. Povinelli, »On the lack of evidence that non-human animals possess anything remotely resembling a 'theory of mind' ", Philosophical Transactions of the Royal Society B: Biological Sciences 362 (2007) 1480, str. 731-744, doi: https://doi. org/10.1098/rstb.2006.2023.

Perry, Susan E.; Barrett, Brendan J.; Godoy, Irene, »Older, sociable capuchins (Cebus capucinus) invent more social behaviors, but younger monkeys innovate more in other contexts «, Proceedings of the National Academy of Sciences 114 (2017) 30, str. 78067813, doi: https://doi.org/10.1073/pnas.1620739114.

Plotkin, Henry, »The power of culture«, u: Barrett, Louise; Dunbar, Robin Ian MacDonald (ur.), Oxford Handbook of Evolutionary Psychology, Oxford University Press, Oxford 2007., str. 11-19.

Premack, David; Woodruff, Guy, »Does the chimpanzee have a theory of mind? «, Behavioral and Brain Sciences 1 (1978) 4, str. 515-526, doi: https://doi.org/10.1017/ S0140525X00076512.

Premack, David; Premack, Ann James, The Mind of an Ape, W. W. Norton \& Co., New York 1983.

Premack, David, »Does the chimpanzee have a theory of mind?«, u: Byrne, Richard W.; Whiten, Andrew (ur.), Machiavellian Intelligence: Social Expertise and the Evolution of Intellect in Monkeys, Apes, and Humans, Clarendon Press, Oxford 1988., str. 94-110.

Premack, David; Premack, Ann James, »Why animals have neither culture nor history«, u: Ingold, Tim (ur.), Companion Encyclopedia of Anthropology: Humanity, Culture and Social Life, Routledge, London 1994., str. 350-365.

Premack, David; Premack, Ann James, Original Intelligence: Unlocking the Mystery of Who We Are, McGraw-Hill, New York 2003

Premack, David; Hauser, Marc D., »Why animals do not have culture «, u: Levinson, Stephen C.; Jaisson, Pierre (ur.), Evolution and Culture, MIT Press, Cambridge, London 2006., str. 275-278.

Premack, David, »Human and animal cognition: Continuity and discontinuity «, Proceedings of the National Academy of Sciences 104 (2007) 35, str. 13861-13867, doi: https:// doi.org/10.1073/pnas.0706147104.

Ramsey, Grant, »Culture in humans and other animals «, Biology and Philosophy 28 (2013) 3, str. 457-479, doi: https://doi.org/10.1007/s10539-012-9347-x.

Read, Dwight W., How Culture Makes Us Human: Primate Social Evolution and the Formation of Human Societies, Routledge, London, New York 2012.

Richerson, Peter J.; Boyd, Robert, Not by Genes Alone: How Culture Transformed Human Evolution, Chicago University Press, Chicago 2005.

Sasaki, Takao; Biro, Dora, »Cumulative culture can emerge from collective intelligence in animal groups«, Nature Communications 8 (2017) 1, str. 15049

Schofield, D. P. et al., »Cumulative culture in nonhumans: overlooked findings from Japanese monkeys? «, Primates 59 (2018) 2, str. 113-122.

Shettleworth, Sara J., Cognition, Evolution, and Behavior, Oxford University Press, New York 2010

Shumaker, Robert W.; Walkup, Kristina R.; Beck, Benjamin B., Animal Tool Behavior: The Use and Manufacture of Tools by Animals, The Johns Hopkins University Press, Baltimore 2011

Spencer, Herbert, The Principles of Sociology, sv. 1, D. Appleton and Company, New York 1876 
Spillman, Lyn, »Culture«, u: Ritzer, George (ur.), The Blackwell Encyclopedia of Sociology, Wiley-Blackwell, Oxford 2007., str. 922-928.

Škorić, Marko; Kišjuhas, Aleksej, »Biološke osnove društvenih hijerarhija«, u: Marinković, Dušan; Šljukić, Srđan (ur.), Promene u društvenoj strukturi i pokretljivosti, Filozofski fakultet u Novom Sadu, Novi Sad 2012., str. 22-86. [2012a]

Škorić, Marko; Kišjuhas, Aleksej, Evolucija i prirodna selekcija: od Anaksimandra do Darvina, Mediterran Publishing, Novi Sad 2012. [2012b]

Škorić, Marko, »Alfred Kreber i koncept superorganskog «, Etnoantropološki problemi 11 (2016.) 1, str. 85-111. [2012a]

Škorić, Marko, »Franc Boaz i uspon kulturnog relativizma«, Kultura polisa 13 (2016.) 30, str. 403-430. [2012b]

Taylor, Paul W., »Are humans superior to animals and plants?«, Environmental Ethics 6 (1984) 2, str. 149-160, doi: https://doi.org/10.5840/enviroethics19846239.

Tomasello, Michael, The Cultural Origins of Human Cognition, Harvard University Press, Cambridge 1999.

Tooby, John; Cosmides, Leda, »The past explains the present: Emotional adaptations and the structure of ancestral environments «, Ethology and Sociobiology 11 (1990) 4-5, str. 375-424, doi: https://doi.org/10.1016/0162-3095(90)90017-Z

Tylor, Edward Burnett, Primitive Culture: Researches into the Development of Mythology, Philosophy, Religion, Language, Art, and Custom, sv. 1, John Murray, G. P. Putnam's Sons, London, New York 1920.

van Casteren, Adam, »Tool Use: Crows Craft the Right Tool for the Job «, Current Biology 27 (2017) 24, str. R1314-R1316, doi: https://doi.org/10.1016/j.cub.2017.10.022.

van Leeuwen, Edwin J. C.; Cronin, Katherine A.; Haun, Daniel B. M., »A group-specific arbitrary tradition in chimpanzees (Pan troglodytes)«, Animal Cognition 17 (2014) 6, str. 1421-1425, doi: https://doi.org/10.1007/s10071-014-0766-8.

van Schaik, Carel Philippus, »Culture in primates and other animals «, u: Barrett, Louise; Dunbar, Robin Ian MacDonald (ur.), Oxford Handbook of Evolutionary Psychology, Oxford University Press, Oxford 2007., str. 103-113.

Vogt, Ludgera, »Culture and Civilization «, u: Ritzer, George (ur.), Encyclopedia of Social Theory, sv. 1, Sage Publications, Thousand Oaks 2005., str. 181-182.

Watson, Stuart K. et al., »Chimpanzees demonstrate individual differences in social information use«, Animal Cognition 21 (2018) 5, str. 639-650, doi: https://doi.org/10.1007/ s10071-018-1198-7

Wellman, Henry M., The Child's Theory of Mind, MIT Press, London 1990.

Wellman, Henry M., Making Minds: How Theory of Mind Develops, Oxford University Press, Oxford 2014.

White, Leslie A., »The Symbol: The Origin and Basis of Human Behavior «, Philosophy of Science 7 (1940) 4, str. 451-463.

White, Leslie A., The Science of Culture: A Study of Man and Civilization, Grove Press, New York 1949.

Whiten, Andrew et al., »Cultures in chimpanzees «, Nature 399 (1999) 6737, str. 682-685, doi: https://doi.org/10.1038/21415.

Whiten, Andrew; Horner, Victoria; Marshall-Pescini, Sarah, »Cultural panthropology«, Evolutionary Anthropology: Issues, News, and Reviews 12 (2003) 2, str. 92-105, doi: https://doi.org/10.1002/evan.1010.

Whiten, Andrew, »The scope of culture in chimpanzees, humans and ancestral apes«, Philosophical Transactions of the Royal Society B: Biological Sciences 366 (2011) 1567, str. 997-1007, doi: https://doi.org/10.1098/rstb.2010.0334.

Whiten, Andrew et al. (ur.), Culture Evolves, Oxford University Press, Oxford 2012. 
Whiten, Andrew, »Animal behaviour: incipient tradition in wild chimpanzees «, Nature 514 (2014) 7521, str. 178-179, doi: https://doi.org/10.1038/nature13759.

Whiten, Andrew, »Culture extends the scope of evolutionary biology in the great apes«, Proceedings of the National Academy of Sciences 114 (2017) 30, str. 7790-7797, doi: https://doi.org/10.1073/pnas.1620733114. [2017a]

Whiten, Andrew et al., »The extension of biology through culture«, Proceedings of the National Academy of Sciences 114 (2017) 30, str. 7775-7781, doi: https://doi.org/10.1073/ pnas.1707630114. [2017b]

Whiten, Andrew, »Cultural evolution in animals«, Annual Review of Ecology, Evolution, and Systematics 50 (2019), str. 27-48, doi: https://doi.org/10.1146/annurev-ecolsys110218-025040.

Yamamoto, Shinya; Humle, Tatyana; Tanaka, Masayuki, »Basis for cumulative cultural evolution in chimpanzees: Social learning of a more efficient tool-use technique «, Plos One 8 (2013) 1, str. e55768, doi: https://doi.org/10.1371/journal.pone.0055768.

Yerkes, Robert M., Almost Human, The Century Co., New York 1925.

\title{
Marko Škorić, Aleksej Kišjuhas
}

\section{Culture in Non-Human Animals and the Evolutionary Origin of Human Culture}

\begin{abstract}
This paper calls into question the ontological privilege of the human species that rests on many misguided ideas. One of these ideas is that Homo sapiens is the only species that possess culture. In this sense, the problem of (defining) culture is emphasised in the context of the so-called minimalist and expansionist definitions. Furthermore, this paper details examples of cultural behaviour in non-human animals. The components commonly considered necessary to speak of true culture are also critically analysed. These components are social learning, language, symbols, the theory of mind, history, tradition, natural pedagogy, and the cumulativeness of culture. Finally, this paper brings attention to the implications of a more adequate, expansionist and naturalistic, definition of culture based on evolutionary (Darwinian) grounds.
\end{abstract}

\section{Keywords}

culture, non-human animals, defining culture, social learning, innovations, tradition, evolution 